\section{Financial system specialization and private research and development expenditure: research for OECD countries}

\author{
Edgard Alberto Méndez-Morales and Carlos Andrés Yanes-Guerra \\ Facultad de Ciencias Economicas, Universidad Militar Nueva Granada, \\ Bogota, Colombia
}

Financial

system specialization

Received 28 October 2019 Revised 19 December 2019 Accepted 11 January 2020

\begin{abstract}
Purpose - The purpose of this paper is to analyse the role that different financial sources and financial specialization have on private research and development (R\&D) activity in OECD countries.

Design/methodology/approach - The authors developed several panel regressions choosing as a final model a two-way random effects regression to understand which funding sources are related to the R\&D expenditure, and how financial specialization has links to the private portion of R\&D aggregated expenditure. The authors include data from the years 2000 to 2016 for OECD countries.

Findings - The results reinforce the critical role that stock markets have in enhancing private R\&D and that bond markets have an inverse relationship with private $R \& D$ national expenditures. The authors do not find evidence of a link between bank sources and private R\&D. Specialized financial systems (banking or market) support innovation in a better way than a mixed arrangement of those two systems.

Practical implications - The findings of this study have considerable policy implications. Policymakers need to be aware of these results, given that some variables related to financial markets, seems to boost the inputs for R\&D. In the long term, this could be a signal that national and regional systems of innovation need a broad view of the factors hampering scientific activity, and also a signal that there are other ways to impact the results of the complex innovation activity through the development of stronger financial systems backing up national systems of innovation.

Originality/value - The authors found that the long discussion about the financial system that a country has to choose to enhance growth with R\&D\&I may have been misleading the public policy. The findings show that rather than a bank or a stock market financial system, economies looking to boost R\&D\&I, must specialize in one of the two systems, deepen these and generate the appropriate policies to promote science, technology and innovation using those financial markets.
\end{abstract}

Keywords R\&D, Bond markets, OECD, Panel models, Stock exchanges, Financial systems

Paper type Research paper

(C) Edgard Alberto Méndez-Morales and Carlos Andrés Yanes-Guerra. Published in Journal of Economics, Finance and Administrative Science. Published by Emerald Publishing Limited. This article is published under the Creative Commons Attribution (CC BY 4.0) licence. Anyone may reproduce, distribute, translate and create derivative works of this article (for both commercial and non-commercial purposes), subject to full attribution to the original publication and authors. The full terms of this licence maybe seen at http://creativecommons.org/licences/by/4.0/legalcode

JEL classification - O16, O57

The authors want to acknowledge the participation of Camilo Anzola and Paola Vargas as research assistants in this project.

Funding: This research was financed by Universidad Militar Nueva Granada under the research project code INV-ECO-2583 named "Los sistemas financieros y la financiación de la actividad innovadora privada en países de la OCDE”.

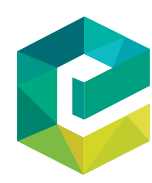

Journal of Economics, Finance and Administrative Science Vol. 26 No. 51, 2021 pp. 41-60 ISSN-L 2077-1886 DOI 10.1108/JEFAS-10-2019-0256 
JEFAS

26,51

\section{Introduction}

Financial markets seem to be deeply related to economic growth. Well-developed financial systems tend to diminish cost transactions and promote efficiency on resource allocation (Beck and Levine, 2004; Beck et al., 2000; Prochniak and Wasiak, 2017; Rajan and Zingales, 1998); therefore, it is expected that countries with a better financial framework, tend to grow higher than those with underdeveloped financial systems.

At the same time, it seems to be a discussion related to the best type of financial system needed to create such growth, whether the development of bank or market based financial systems, given that one type of financial system could be better than the other to promote those efficiencies (Arestis et al., 2001; Beck and Levine, 2002, 2004; Carlin and Mayer, 2003; Demirgüç-Kunt and Maksimovic, 2002; Durusu-Ciftci et al., 2017; Levine, 1997; Zysman, 1984); however, the fact that there are high growth rates in countries with both type of systems, tend to highlight the fact that there is no only one type of financial system related with economic growth (Beck and Levine, 2004; Hasan et al., 2018; Lee, 2012; Luintel et al., 2008) or at least, that the real discussion has to be focused not on the type, but on how those systems interact to support economic growth.

On the other hand, in recent decades, the evolution of studies describing the technological change and the economics of innovation, have concluded that innovation creates economic growth through productivity increases (Akcigit and Kerr, 2018; Crepon et al., 1998; Romer, 1990; Solow, 1956; Stulz, 2003). Following that idea, it is a fundamental task for governments around the world to support innovation activities to generate economic growth in the long term. At the same time, there are several ways in which governments can help to increase innovation activities, for example, through the development of direct interventions like, granting subsidies to innovative firms, the generation of tax incentives for companies making R\&D (Czarnitzki and Hussinger, 2018), or the generation of indirect measures like, promoting innovation ecosystems through the generation of strong institutions related with innovation (Barbosa and Faria, 2011; Furman et al., 2002; Lundvall, 1999; Lundvall, 2010), some of those institutions could be universities, research centres, government organizations or even, a robust financial framework related with innovation.

Related to the last point, most of the time, financial factors are the ones reported by firms like the essential ones hampering innovation results. Even when these are not the only innovation barriers perceived by firms, those factors can diminish innovation outputs especially for small and high technology firms (Baldwin and Lin, 2002; D'Este et al., 2012; Iammarino et al., 2009; Madrid-Guijarro et al., 2009; Pellegrino and Savona, 2017).

In relation to this issue, is essential to note that policymakers can not affect the way firms gather internal funds unless they grant subsidies to all innovative companies; therefore, policymakers need to support the development of well-functioning financial systems in which information asymmetries descend, to allow financial institutions and firms to generate a meeting point in which cash goes from the pockets of investors and creditors to innovation projects inside firms.

In this document, we want to determine if the development of robust financial systems, tends to reinforce the way that countries invest on innovation (measured as the proportion of total R\&D performed by the private business within a country). Still, most importantly, we want to determine if financial specialization in bank and market financial systems, tends to reinforce the private R\&D\&I aggregated expenditures of firms. For that propose, we use data of OECD countries for the 2000-2016 period, and we use measures of financial development such as bank concentration, private credit to firms as a GDP percentage, stock 
market value as a GDP percentage, and volume of corporate bonds traded on the market as a percentage of GDP. All these measures are aggregated proxies of external sources of finance for firms. At the same time, we use a variable considering the specific character of each country's financial system, not to understand what type of financial system is better to support innovation, but as a way to understand how financial market specialization is related to the R\&D activity. Our main contribution goes into this direction; we want to understand if $R \& D$ private expenditure is affected not only by the choosing of a specific financial system, given that bank and stock markets can support private innovation activities in its way; instead, we want to understand if the specialization of those arrangements creates enhancements on $R \& D$ private expenditures.

Given the unique characteristics of each of the funding sources used for companies to fund R\&D\&I, and the unique framework of each financial systems within countries, in this research, we propose some hypothesis related to the relationship between those sources, financial systems arrangements, and innovation:

H1. Banking markets have a positive relationship with private R\&D expenditures. Companies seeking to finance their innovation ventures with external resources, must demonstrate to banks that those investments are worthy; however, most of the time, companies cannot demonstrate that worth to financial institutions given the fact that there are information asymmetries; however, once banks found a technically reliable and profitable project, those institutions tend to back up highquality projects; therefore, we expect to found a positive relationship between private investments in R\&D and bank financing.

H2. Stock exchange markets have a positive relationship with private R\&D expenditures. Given that innovation projects are highly risky and long-term endeavours, and that stock markets are the types of investments searched by investors wanting to face risk, we hypothesize that there must be a positive relationship between aggregated measures of stock markets and private innovation activities.

H3. Bond markets have a negative relationship with private R\&D expenditures. Most of the time, bond markets are used by firms to back up non-risky projects, because bonds are related to fixed periodical payments; therefore, a company seeking to finance a risky project with bonds will face high uncertainties related to bond payments and obligations. Thus, the upraising of low-risk level bond markets should diminish available funding for innovation.

H4. Specialized financial systems are positive related to R\&D expenditures. Different literature sources seem to find that there is a relationship between $R \& D$ and stock markets. Still, at the same time, there is also literature supporting that bank markets are also a good funding source for innovation activities. We hypothesize that bank and stock markets can support private innovation activities in their way; therefore, specialized markets (bank or stock markets) must relate to R\&D expenditures.

Our paper is structured as it follows: Section 2 introduces literature related to financial systems and innovation, Section 3 describes the methodology used, Section 4 discusses the results of the econometric models, and finally, Section 5 introduces conclusions and results' implications. 


\section{JEFAS \\ 26,51}

\section{Literature review}

The seminal writings of Schumpeter generate an initial way to consider the importance of innovation on economic growth, at the same time, these writings point out a relationship between financial systems and cash provision to entrepreneurial and innovation activities, and even when today there are a big set of factors that we do not know about this relationship, there are also some proved factors through empirical and theoretical research since these early works of Schumpeter.

First, innovation activities are affected by information asymmetry; this market failure elevates the financial cost of cash flows related to R\&D\&I ventures and causes a deficit of external cash flow directed to those activities. At the same time, innovation project results tend to be intangible, and therefore, there is a difficulty trying to appropriate those results; this is one of the reasons behind the existence of an international patent system. Also, innovation is a long-term investment, which elevates uncertainty about its results, and most of the time moves away from companies from this type of investment. Those market failures raise the risk of innovation investments compared with investments in traditional assets inside a company (Hall and Lerner, 2009), decreasing the general level of R\&D\&I of society (Arrow, 1972; Nelson, 1959).

Simultaneously, firms perceive that there are several financial impediments related to money collection for innovation ventures. For one side, internal resources for innovation most of the time are scarce, and the internally generated cash flow generally is used to cover other types of necessities, especially in cash-restrained firms (Brown et al., 2009). On the side of external resources, the already mentioned market failures elevate the cost of available funding sources (Bank credits, bonds, equity, venture capital) creating an elevated perception of external cash deficit to back up innovation (D'Este et al., 2012; Hall and Lerner, 2009; Iammarino et al., 2009; Pellegrino and Savona, 2017); this perception tend to be more elevated in high technology, young and small companies (Hall and Lerner, 2009 and Méndez-Morales, 2019) compared with their counterparts.

On the other hand, there is a branch of literature proposing that the differences in innovation inputs and outputs around the World are related to the mix of institutional frameworks within countries. This research branch began with the work of Freeman (1995, 1987), Lundvall $(1999,2010)$ and Nelson (1993); for Freeman, these relationships are known as National Systems of Innovation (NSI), that he defined as "the network of institutions in public and private sectors whose activities and interactions initiate, import, modify and diffuse new technologies." Following this idea, in countries in which the private investment in R\&D\&I is low, one can think that the development of strong organizations backing up innovation is necessary, in that sense, one of the main functions of those organizations and institutions is to ease how firms perceive and face financial impediments to innovation. Edquist (2005) proposes that one of the main activities of NSI is to back up the financing of private innovation activities, facilitating commercialization, and adoption of technologies. In this sense, for countries with low amounts of private R\&D expenditures, one can think that some of the institutional and organizational financial frameworks necessary to back up innovation funding, still need to be generated. In this context, the study of the relationship of financial systems and innovation could give us some clues about the policy actions needed to develop a strong national system of innovation backing up the financing of innovation ventures.

The study of the relationship between financial systems and innovation is not comprehensive; however, there are some examples of researchers working on it. Hsu et al. (2014) show that countries in which stock markets are active, tend to have higher growths on innovation expenditures, at the same time, highlight the importance of legal protection 
for stockholders as a way to generate positive innovation outcomes, this is logic in the sense that venture capital is a way to finance high technology firms. Those investments need to be backed by robust policies to protect investors. At the same time, Tee et al. (2014) propose that all together, the development of bank and stock markets, tends to be related to substantial innovation investments. Simultaneously, Acharya and Xu (2017) shown that the development of active banking markets is related to the growth of patent applications.

Acharya and Xu (2017) and Da Rin and Penas (2007) propose that public traded and private equity firms, have different views regarding R\&D investments. Public traded firms tend to have more R\&D expenditures, and their patents, tend to have a more significant commercial impact than private firms, this is, the quality and value of those inventions are higher than their private non-traded counterparts. At the same time, firms with reliable risk control systems tend to have more likelihood to receive government funds and higher R\&D expenditure. Generally, this kind of firm goes public on stock markets, given their risky nature.

At the same time, Maskus et al. (2012) find that bond markets tend to have a high impact on innovation intensities, especially from firms financially restricted. In the same direction, Gur and Avşar (2016) demonstrate that financially restricted firms tend to export more R\&D-related products when more specialized financial systems finance them. These results could highlight that the type of financial system in which a firm is immersed tends to benefit some characteristics of innovation activity. Therefore, the study of the relationship between innovation results and financial system frameworks is a fundamental one.

All this literature points out the relevance of financial systems as a critical factor in supporting innovation expenditures and ventures. However, literature seems to be contradictory, with some studies demonstrating that bond markets tend to be the most related to innovation; on the other side, some literature points out the importance of stock markets, and some tend to signal the credit markets like the ones actively supporting innovation. These contradictory results seem to be a gap in the literature, given that policymakers could receive mixed signals related to the type of financial system that a country has to back up to reinforce private R\&D\&I funding.

On the other side, literature seems to privilege methodologies to classify countries in bank or market financial systems (Levine, 2002), forgetting that both types of markets could reinforce private $R \& D \& I$ expenditures in its way, therefore, with this research, we want to understand if the specialization of bank or market financial systems is related with better private expenditures in R\&D\&I, and that what is essential is the deepening of any of those systems forgetting to choose between one of them. This analysis could be significant in terms of policy decisions, given that contrary to what is held in most of the literature, it is possible that any specific financial systems, could enhance private R\&D\&I expenditures, and what is needed is to develop particular policies to narrow the relationship between financial markets and entrepreneurs and innovators on those financial systems.

\section{Methodology}

Using data collected from World Bank (Čihák et al., 2018) and UNESCO data bank between the years 2000 and 2016, we developed an econometric strategy through estimations of longitudinal models. These models group observations by cross-section and by time series, taking the $\mathrm{X}_{\mathrm{it}}$ form, where (i) considers individuals, in our case, OECD countries, and $(t)$ takes into account each year for the interval 2000-2016. At the same time, this method allows us to take into account the effect of heterogeneity among individuals over time. 
JEFAS 26,51

The independent variable in our models is the proportion of $R \& D$ performed by the business sector within each country, and we include a vector of covariates $\mathrm{X}_{\mathrm{it}}$ that is divided into four subgroups, the first one taking into account countries economic stability; therefore, we include per capita energy consumption (as a proxy of GDP per capita [1]), exchange rate index against the dollar and inflation rate, all these as macroeconomic conditions control variables; we assume that stable markets tend to ease R\&D private expenditures.

The second group of variables, considers external financing sources of firms to perform R\&D ventures, these are private credit to firms, stock market capitalization and volume of corporate bonds traded in the market, whit these variables, we want to understand which type of funding sources are better suited to support R\&D.

Third, we include a control variable considering the development of national systems of innovation, which we measure as the number of employees on private companies working directly on R\&D in full-time equivalent. With this variable, we are trying to control for most specialized national innovation systems, that at the same time, have more researchers and higher R\&D expenditures; therefore, is a basic fact not directly related to the development of financial systems, and we need to control it.

Lastly, we include two variables measuring financial structure within countries, bank concentration, and our own performed dummy variable considering specialization of financial systems (methodology explaining the way we calculate this variable is showed in Appendix 1). For those nations where the two systems (banking and stock markets) were active, we take the value of zero, meaning that the country has a mixed financial system. For countries in which only one of the dimensions is present, we use the value of one, meaning that there is a specialized financial system (bank or market based), this because we want to understand if the deepening of bank or market systems conditions reinforces private R\&D\&I. The inclusion of this variable is a novel approach to finance-innovation literature, given that most of the time, researchers want to understand what type of financial system is better, in our approach, it is possible that any specific financial system, could enhance private R\&D\&I expenditures, and what is essential is the deepening of those systems instead of its exclusivity. The definition of variables and sources of data can be seen in Table 1, and the resume of variables could be seen in Appendix 3.

Our estimations were performed with two strategies, in the first one, we consider the assumption that private R\&D is related to short-term financial sources, therefore including this last set of variables in contemporaneous terms. For this strategy, we performed the next equation:

$$
\begin{aligned}
Y_{i t} & =\phi Y_{i t-\rho}+\alpha X_{i t}+\vartheta_{i}+\varepsilon_{i t} ; \forall i=\text { Colombia, Spain }, \ldots, N ; \\
t & =2000,2001, \ldots, 2016
\end{aligned}
$$

We began this model with the insertion of a lag term of independent private R\&D expenditure variable $\left(Y_{i-t}\right)$, which allows us to control for endogeneity of independent variables with the dependent variable (Arellano, 2003). In this case, we suspect the presence of endogeneity, because $R \& D$ expenditure tends to increase firm revenues in the long term, and this makes companies look for internal and external financial sources such as banks, bonds or stock markets to finance new $R \& D$ ventures, which will elevate the $R \& D$ private expenditure.

In this model, the $\left(\vartheta_{i}\right)$ parameter refers to the error term taken by each individual (countries), and that is named fixed effects estimator. This estimator needs to be correlated with covariates, should not vary among time, but should vary among countries. An 


\begin{tabular}{l} 
Variable \\
\hline Gross expenditure on R\&D \\
performed by business \\
enterprise \\
Electric power consumption \\
(kWh per capita) \\
Exchange rate index. Base \\
year 2010 \\
Annual inflation rate (\%) \\
Domestic credit to private \\
sector (\% of GDP)
\end{tabular}

Market capitalization of listed domestic companies ( $\%$ of GDP)

Corporate bond issuance volume to $\operatorname{GDP}(\%)$

Total R\&D personnel (full time equivalent) - business enterprise

\section{ID}

Description

gerd

Calculated as gross expenditure on R\&D

financed by business enterprise as a proportion of total R\&D expenditure

epc

Electric power consumption measures the production of power plants and combined heat and power plants less transmission, distribution and transformation losses and own use by heat and power plants. In this case, the EPC variable is a proxy of GDP per capita

exrti Real effective exchange rate is the nominal effective exchange rate (a measure of the value of a currency against a weighted average of several foreign currencies) divided by a price deflator or index of costs

irate

Inflation as measured by the consumer price index reflects the annual percentage change in the cost to the average consumer of acquiring a basket of goods and services that may be fixed or changed at specified intervals, such as yearly. The Laspeyres formula is generally used

banks Domestic credit to private sector refers to financial resources provided to the private sector by financial corporations, such as through loans, purchases of nonequity securities and trade credits and other accounts receivable, that establish a claim for repayment. For some countries, these claims include credit to public enterprises. The financial corporations include monetary authorities and deposit money banks, as well as other financial corporations where data are available (including corporations that do not accept transferable deposits but do incur such liabilities as time and savings deposits). Examples of other financial corporations are finance and leasing companies, money lenders, insurance corporations, pension funds and foreign exchange companies

mkcap Market capitalization (also known as market value) is the share price times the number of shares outstanding (including their several classes) for listed domestic companies. Investment funds, unit trusts and companies whose only business goal is to hold shares of other listed companies are excluded. Data are end of year values

bonds Ratio of new corporate bond issuance volume by private entities in industries other than finance, holding companies and insurance to GDP

p_fte In the context of R\&D statistics, the business enterprise sector comprises all resident corporations, including not only legally incorporated enterprises, regardless of the
Source

UNESCO

Financial system specialization

World Bank

47

World Bank

World Bank

World Bank

World Bank

World Bank

UNESCO

Table 1.

Variables, definitions and sources 
Bank market concentration $(\%)$

Financial system specialization conct

Assets of the

a share of total commercial banking assets.

Total assets include total earning assets, cash and due from banks, foreclosed real estate, fixed assets, goodwill, other intangibles, current tax assets, deferred tax assets, discontinued operations and other assets

fss Constructed using principal component analysis, starting with a subgroup of variables related to stock markets and a subgroup of variables related to banking systems. For those nations where the two factors (banking and stock markets) were strong, we take the value of zero, meaning that the country has a mixed financial system. For countries in which one of the dimensions were strong, we use the value of one, meaning that there is a specialized financial system (bank or stock-based) (In Appendix 1, we are showing the full methodology to construct this variable)
Source

World Bank

Own calculations based on World

Bank data

Source: Own calculations based on UNESCO and World Bank data

excellent example of this type of variance could be local financial laws, which we do not include in our model, and therefore are captured for $\left(\vartheta_{i}\right)$, are related to covariates such as banking concentration, or market capitalization, are generally fixed over time, and could vary among OECD countries. However, if this term correlates with covariates or independent variable, then the best approach is to estimate the model by a random-effects model:

$$
Y_{i t}=\phi Y_{i t-\rho}+\alpha X_{i t}+\mu_{i t} ; \forall i=\text { Colombia, Spain, .., } N ; t=2000,2001, \ldots, 2016
$$

where, $\mu_{i t}=\vartheta_{i}+\varepsilon_{i t}$, is taken as an independent term, and must be estimated with a generalized method of moments methodology. For models of equations (1) and (2), we 
developed a Hausman test and found that obtained parameters are consistent with a fixedeffects model (Appendix 2).

For our second strategy, we relax the assumption of strict exogeneity of estimators, considering countries and time variance, and, therefore, obtaining a dynamic two-way random effects panel model. Then, our model will be expressed as:

$$
\begin{aligned}
Y_{i t} & =\phi Y_{i t-\rho}+\alpha X_{i t}+\mu_{i t} ; \forall i=\text { Colombia, Spain }, \ldots, N ; \\
t \& \rho & =2000,2001, \ldots, 2016
\end{aligned}
$$

In this methodology, the error term is discomposed into three variance terms; according to Amemiya (1971), $\mu_{i t}=\vartheta_{i}+\lambda_{t}+\varepsilon_{i t}$, where $\vartheta_{i}, \lambda_{t}, \varepsilon_{i t} \sim\left(0, \sigma^{2}\right)$, and are independently and identically distributed. The $\left(\vartheta_{i}\right)$ term, is the within fixed effect parameter, the $\left(\lambda_{t}\right)$ term measures the time effect not included directly in the regression, and that could be measuring an extraordinary situation like an oil bonanza or a financial crisis. In our case, these two phenomena are valid, given that the World faced two financial crises in our time span (2001, 2008) and oil prices rise enormously in 2009 and 2010, and both effects could affect financial provision for R\&D in companies for the sample of countries. The $\left(\varepsilon_{i t}\right)$ term accounts for not observed time and countries effect of the model. To estimate this model a set of binary variables vectors were constructed:

$$
U=Z_{\mu} \mu+Z_{\lambda} \lambda+\varepsilon
$$

where $Z_{\mu}$ is a vector of dummy variables for each country; $Z_{\lambda}$ is a vector of dummy variables for each year (2000-2016), and $\varepsilon^{\prime}:\left(\varepsilon_{11}, \ldots, \varepsilon_{1 T}, \ldots, \varepsilon_{N T}\right)$ is a vector of general residuals of the model. The estimation ends up being consistent and robust when the error term is controlled and discomposed into these three factors, and if is estimated for a balanced panel, which is our case. With these vectors is possible to develop our estimation through a two-way random effects model, controlling by individual and time effects and minimizing model residues as follows:

$$
\mathfrak{E}=E\left(U U^{\prime}\right)=Z_{\mu} E\left(\mu \mu^{\prime}\right) Z_{\mu}^{\prime}+Z_{\lambda} E\left(\lambda \lambda^{\prime}\right) Z_{\lambda}^{\prime}+\sigma_{\varepsilon}^{2} I_{N T}
$$

where Kronecker products of individuals and time are established:

$$
\mathfrak{E}=\sigma_{\mu}^{2}\left(I_{n} \otimes J_{T}\right)+\sigma_{\lambda}^{2}\left(J_{n} \otimes I_{T}\right)+\sigma_{\varepsilon}^{2}\left(I_{n} \otimes I_{T}\right)
$$

Being covariance expressed as:

$$
\text { Covariance }\left(u_{i t}, u_{j s}\right)\left\{\begin{array}{clll}
\sigma_{\mu}^{2}+ & \sigma_{\lambda}^{2}+\sigma_{\varepsilon}^{2} & i=j, \quad s=t \\
\sigma_{\mu}^{2} & 0 & i=j, \quad s \neq t \\
0 & \sigma_{\lambda}^{2} & i \neq j, \quad s=t \\
0 & 0 & i \neq j, \quad s \neq t
\end{array}\right.
$$

We stay with this final set of models because estimation is consistent and robust when we control and decompose the error term of the dynamic panel if, at the same time, the 
JEFAS

26,51

estimation begins with a balanced panel, which is our case; however, in Table 2, we present all our models as robust checks. Lastly, given that innovation is a long-term process, is expected that the effect that financial sources have on private GERD variable, will also be found in the long term; therefore, we include specific models with a vector of lagged $\left(\mathrm{X}_{\mathrm{t}-1}\right)$ financial sources (private credit to firms, stock market capitalization and volume of corporate bonds traded in market), to consider this fact. Lastly, we perform models in which the contemporaneous financial variables and their lags are included to understand the simultaneous effect of short- and long-term financial sources over R\&D private expenditure.

\section{Results and discussion}

The results of our models are presented in Table 2. In Columns 1, 3 and 5, we present the fixed-effects models (robust checks), and in Columns 2, 4 and 6, our chosen model, two-way random effects, is presented.

\subsection{Macroeconomic conditions}

For all models, the lag of the private R\&D expenditure $\left(\operatorname{gerd}_{t-1}\right)$ turns to be significant and positive related to contemporaneous private $R \& D$ expenditure. The effect estimated by our models is that for each $1 \%$ of increment in previous expenditure, the contemporaneous private proportion of $R \& D$ will increase between 0.425 and $0.61 \%$. We include this lag given possible endogeneity issues; however, this result tells us that as it was concluded by Dosi (1982), in the case of individual firms, and by Redding (2002), in the case of an entire economy, there is enough evidence to say that private R\&D in OECD countries tend to follow a historical path, this is, countries in which private R\&D expenditure was high in the past, would tend to have higher private $R \& D$ expenditures in the future.

Electric power consumption $(e p c)$ is not significant in any of the models; we include this variable as a proxy of GDP per capita to solve possible endogeneity issues; we can say that in more industrialized countries, in which the income is higher, private companies not necessarily tend to invest a higher proportion than its counterparts; this results are related with the ones presented in Lederman et al. (2014), that shows that for Latin America, per capita GDP does not explain total R\&D, given that investments in R\&D predicted by this variable should be higher, concluding that there is other not observable variables affecting the level of total R\&D expenditure.

Results of the exchange rate (exrti) are related to the ones in Becker and Pain (2003) and Jaumotte and Pain (2005). It seems that appreciation of exchange rates in OECD countries, tend to increase private expenditure on $R \& D$, or what is the same, exchange rate depreciation, diminish private expenditure on R\&D. For each $1 \%$ of additional depreciation rate, private $R \& D$ proportion will decrease between 0.025 and $0.062 \%$. Various reasons could explain this effect; in the first place, it is possible that an appreciation of the exchange rate against the dollar tends to raise internal competition in favour of multinational companies. National firms could be aware that this level of competition needs more investments in R\&D to surpass competence. Second, some companies investing in R\&D could move their operations overseas, given that it is cheaper to operate in other countries with more favourable exchange rates.

Inflation rate (irate) has a negative and significant relationship with private R\&D proportion with a decrease in this variable between 0.093 and $3.36 \%$ after a $1 \%$ increase of inflation rate; there is some empirical evidence of this relationship in the literature (Chu et al., 2015, 2019; Chu and Lai, 2013). As we understand this phenomenon, firms that perceive that the economy is unstable, represented by an elevated inflation rate, and by an increasing exchange rate, tend to decrease R\&D investments given that uncertainty is higher. 


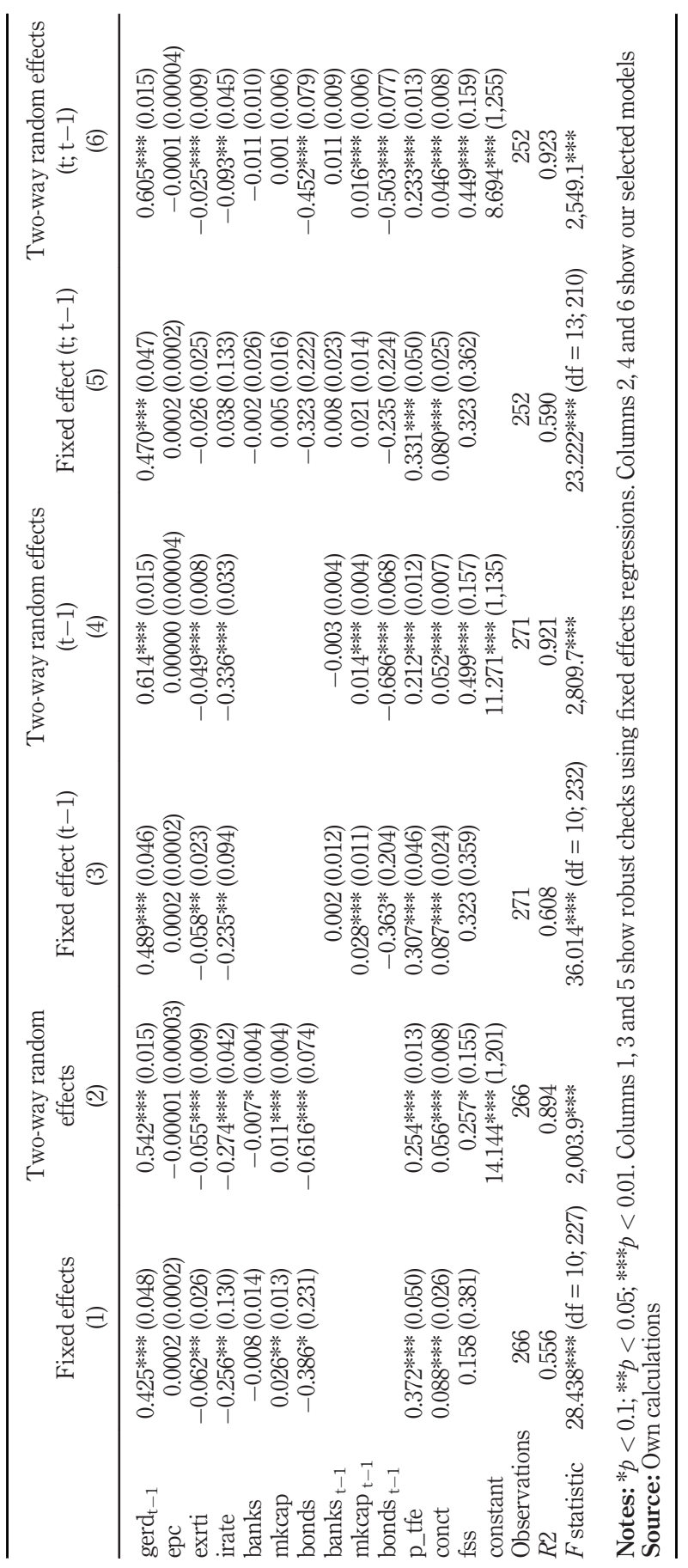

Financial

system

specialization

51

Table 2.

Results of econometric estimations 
JEFAS 26,51
Therefore, the risk related to $R \& D$ ventures exacerbates. Results of exchange and inflation rates show that macroeconomic stability is fundamental to increase $R \& D$ investments.

\subsection{Funding sources for $R \& D$}

Regarding $H 1$, domestic credit to the private sector (banks) is not significative related to private $R \& D$ proportion in three of four models, furthermore, for contemporaneous models $(1,2,5$, and 6$)$ this variable seems to have a negative but not significative relationship with private R\&D therefore, we cannot say that credit volume from banks has a significative relationship with R\&D activity in OECD countries, but, the sign of the variable and the fact that in the two-way model (Model 2) the variable is significative, tend to make us think that banks are not suited to finance innovation. At the same time, when we use the lag of the variable to understand the long-term relationship with private R\&D (Models 3, 4, 5 and 6), bank financing is not related to private $R \& D$ expenditure; therefore, there are no contemporaneous or long-term relationships between bank sources and private R\&D expenditure, $H 1$ cannot be proved.

When we analyse $H 2$, the contemporaneous variable capitalization of domestic companies (mkcap), is positively related to R\&D private expenditure. The effect of this variable after an increase of $1 \%$ could be between 0.011 and $0.026 \%$ of private R\&D proportion. When we analyse the lag of the variable, the effect is between 0.014 and $0.028 \%$. An essential factor is that when we include in Models 5 and 6, both the contemporaneous and the lagged variable, the contemporaneous effect is no longer significant. A plausible explanation for this could be that stock exchange markets are suitable institutions to support private R\&D projects in the long-term, given that R\&D\&I ventures are long-shot bets for companies; therefore, firms tend to finance their innovation ventures with sources suitable for the long-term nature of their projects, like the ones related with equity financing in stock markets. There is some evidence about these results in research like the one by Brown et al. (2009), Hsu et al. (2014) and Tee et al. (2014). H2 was proved, stock exchange markets have a positive relationship with private $R \& D$ expenditure.

Bond markets (bonds) seem to be negative and significative related to our dependent variable in 3 of 4 models, and it appears that the volume of this type of market negatively affects R\&D private expenditure. At the same time, the lag of the variable is negatively related to private $R \& D$ expenditure; it seems that corporate bond volume in the long term also diminishes the proportion of funds available for R\&D.

As we discuss in the introduction section, bond instruments are used to back up nonrisky projects given that fixed payments related to most of this type of financial instruments, need to have a protected cash flow to secure payments; therefore, this type of financial instruments are not suited for R\&D financing. At the same time, one possible reason to explain this result is that innovation is a risky venture, and most of the time, corporate bond investors are trying to avoid risky ventures. Given the low investment amounts, incentives for investors to monitor firm projects are low, and given that R\&D projects are risky, it will require a type of financing more suited for risk, especially if investors are not willed to closely monitoring contracts. Also, Denis and Mihov (2002) show that bonds, as public debt securities, are more suited for big firms with good loan histories. Given that most of the time, this type of firm is an exception, SME companies wanting to use bonds as a way to finance R\&D expenditures cannot use these financial instruments. Lastly, if we suppose a given economy with limited financial resources, investments in bond markets will create a displacement effect that does not allow companies to finance R\&D with another type of financial source such as stock exchanges; therefore, the negative sign of 
the variable explains this fact. $H 3$ was proved, bond markets have a negative relationship with private $R \& D$ expenditure.

Financial system specialization

\subsection{National systems of innovation}

We include a variable considering the development of national systems of innovation, counting the number of employees working on R\&D on business within countries $\left(p \_f t e\right)$. In all models, the variable was positive and significative related to private R\&D expenditure. This result is logical given that most of the expenditure effort of companies investing in $\mathrm{R} \& \mathrm{D}$, is associated with the generation of capabilities and intangible assets related to knowledge; therefore, a higher number of $\mathrm{R} \& \mathrm{D}$ employees must be linked with higher private proportions on $R \& D$ expenditures. At the same time, knowledge generation within firms is fundamental to generate output in the innovation process, as it was proposed by Cohen and Levinthal (2000), given that the absorptive capacity of employees produces more and better capabilities to perform R\&D\&I and enhances collaborative capacities inside and outside of the R\&D departments; therefore, countries with more R\&D employees will have more likelihood to generate better innovation outputs and will tend to expend more on R\&D in the future.

\subsection{The financial structure of OECD countries}

Bank concentration (conct) seems to be related to higher levels of private R\&D expenditure, and it seems to be contradictory given that competence inside banking markets tends to open banks to lend more money to risky ventures. In the research of Carlin and Mayer (2003), the effect of bank concentration depends on the degree of economic development of studied countries, been knowledge skilled industries of developed economies supported by higher atomization of banking systems; however, in the case of developing countries, concentration seems to back up the development of this type of industries. Given that the focus of our analysis was not the determination of the differences between developed and underdeveloped countries, we do not divide our sample into these typologies, so, it is possible that our results are related to this issue; however, more research needs to be done to understand this singularity.

Regarding H4, we introduce our variable of financial systems specialization; in all of the two-way random effect models (Columns 2, 4 and 6 of Table 2), the variable is positive and significantly related to $R \& D$ private expenditures. Given that $f_{S s}$ is a dummy variable equal to 1 if the country has banking or stock market specialized markets, and 0 if the country has a mixed financial system, our results reinforce the fact that specialization is related to higher proportions of private R\&D expenditures. Literature tends to analyse if banking or stock markets are better for economic growth and if any of those markets are better suited to generate R\&D financing. Our results seem to be in line with the ones in Levine (2002, 2004) and Gur and Avşar (2016), the discussion is not whether bank-based or market-based is better for economic growth, or if any of those systems promote R\&D private expenditure. Any of those systems could support in its way R\&D activity; therefore, specialization of bank-based and market-based financial systems could generate conditions to enhance firms' investments in R\&D. However, the fact that our bank measure is not significant, and that market capitalization is highly significant, made us think that maybe, market-based financial systems could generate more incentives to innovation activity. Nevertheless, it is important to note that there are strong complementarities between the functioning of banks and stock markets and that their coexistence is necessary to enhance R\&D. 
JEFAS

26,51

\section{Conclusions}

We analysed the role that financial markets have on the proportion of private R\&D expenditure in OECD countries between 2000 and 2016, for this, we used a two-way random effects panel model approach, to understand which type of financial sources (banks, bonds and stock markets), are related with private research activity within those countries. At the same time, we researched the relationship between financial markets specialization and R\&D activity, not to understand which type of financial system is better suited to support R\&D\&I expenditures, that is the typical approach on literature, but to understand if a mixed arrange of those systems, or specialization of any of them, could support innovation finance in a better way.

We found that macroeconomic stability is fundamental for private research and development activity within countries; increases in variables such as exchange rate index and inflation affects the proportion of R\&D private expenditures negatively. We found evidence that bond markets, negatively affect the portion of expenditure invested by private companies in the OCDE, maybe because of their short-term nature. At the same time, we do not find evidence relating bank activity to R\&D investments; however, we do find that bank concentration is related with more private $R \& D$ expenditures proportion, this result could be because we have countries in different stages of development in our sample; however, we need to perform more research to understand this result fully. Stock market volume seems to be highly related to $R \& D$ aggregated expenditures; this result seems logical given that these markets have a long-term and risky nature, and we can say that this type of funding source seems to be better suited to support research activity than banks or bonds sources.

Path development of national systems of innovation relates to private R\&D expenditure; countries seem to continue their long-term investment tradition as it appears by the results of the full-time researcher's employment variable that correlates positively with GERD. Therefore, a critical message for underdeveloped countries is that the investment path needs to begin at some moment; this path could be supported by public policies that privilege researchers recruiting in private industry, that in the long-term, will generate its own acceleration for private $R \& D$ expenditure.

We include a novel approach to research if a mixed, or a specialized arrangement of financial systems is better to support R\&D private investments, to that end, we include a variable constructed using a principal component method taking several variables of financial development; using this variable we classify OECD countries in specialized (bank or market) or a mixed financial system. Our results reinforce the fact that financial specialization relates to research activity; however, this specialization is independent of the type of financial markets developed in a specific country, this is, countries with bank-based markets and countries with marked based financial markets could independently, generate more funds dedicated to private research and development activity. These results are related to the ones of Gur and Avşar (2016) that highlight the fact that specialized financial systems (any of them) relate to high technology exports, and with the ones of Levine (2002) that post that the important discussion for economic growth is not about the type of financial systems of a country, but about the way economies uses financial systems to boost growth. The fact that with our approach, we found that any financial arrangement could support private R\&D investments, contributes to finance-innovation literature; the main discussion is not which type of system supports better private R\&D, but how to take advantage of financial systems characteristics to enhance national systems of innovation. Policymakers need to be aware of these results, given that some variables related to financial markets, seem to boost the inputs for innovation. In the long term, this could be a signal that national and regional systems of innovation need a broader view of the factors hampering scientific activity but 
also a signal that there are other ways to impact the results of the complex innovation activity through the development of stronger financial systems backing up national systems of innovation.

Results of our specialization novel variable, in conjunction with the effects of banks, bonds, and stock market capitalization variables, generate more research questions related to this topic, for instance, what communicating vessels make banks and stock markets reinforce the production of R\&D inputs and outputs? How can corporate or government bond markets create a framework in which private R\&D can bloom? Do developed and underdeveloped countries differ in their provision of funds to $R \& D$ and in the way that financial sources interact with innovative activities?

\section{Note}

1. We do not include GDP per capita directly to avoid possible endogeneity problems. Energy consumption is highly correlated with GDP; therefore, we choose this variable to avoid these issues. On a primary set of regressions, we use GDP per capita finding counterfactual results, been GDP negative and significantly related with GERD variable.

\section{References}

Acharya, V. and Xu, Z. (2017), "Financial dependence and innovation: the case of public versus private firms", Journal of Financial Economics, Vol. 124 No. 2, pp. 223-243, available at: www. sciencedirect.com/science/article/pii/S0304405X16300101

Akcigit, U. and Kerr, W. (2018), "Growth through heterogeneous innovations”, Journal of Political Economy, Vol. 126 No. 4, pp. 1374-1443, available at: www.journals.uchicago.edu/doi/10.1086/697901

Amemiya, T. (1971), "The estimation of the variances in a variance-components model", International Economic Review, Vol. 12 No. 1, pp. 1-13, available at: www.jstor.org/stable/2525492?origin= crossref

Arellano, M. (2003), Panel Data Econometrics: Advanced Texts in Econometrics, Oxford University Press, Oxford.

Arestis, P., Demetriades, P. and Luintel, K. (2001), "Financial development and economic growth: the role of stock markets", Journal of Money, Credit and Banking, Vol. 33 No. 1, p. 16, available at: www.jstor.org/stable/2673870?origin=crossref

Arrow, K.J. (1972), "Economic welfare and the allocation of resources for invention", Readings in Industrial Economics, RAND Corporation, pp. 219-236, available at: www.rand.org/pubs/papers/P1856.html

Baldwin, J. and Lin, Z. (2002), "31 Research policy impediments to advanced technology adoption for Canadian manufacturers", Research Policy, Vol. 31 No. 1.

Barbosa, N. and Faria, A. (2011), "Innovation across Europe: how important are institutional differences?”, Research Policy, Vol. 40 No. 9, pp. 1157-1169, available at: www.sciencedirect.com/ science/article/pii/S0048733311000989

Beck, T. and Levine, R. (2002), "Industry growth and capital allocation: does having a market or bankbased system matter?”, Journal of Financial Economics, Vol. 64 No. 2, pp. 147-180, available at: www.sciencedirect.com/science/article/pii/S0304405X02000740

Beck, T. and Levine, R. (2004), "Stock markets, banks, and growth: panel evidence", Journal of Banking and Finance, Vol. 28 No. 3, pp. 423-442, available at: www.sciencedirect.com/science/article/pii/ S0378426602004089

Beck, T., Levine, R. and Loayza, N. (2000), "Finance and the sources of growth", Journal of Financial Economics, Vol. 58 Nos 1/2, pp. 261-300, available at: www.sciencedirect.com/science/article/pii/ S0304405X00000726 
JEFAS 26,51

Becker, B. and Pain, N. (2003), "What determines industrial R\&D expenditure in the UK?”, National Institute of Economic and Social Research, pp. 1-34, available at: http://citeseerx.ist.psu.edu/ viewdoc/download?doi=10.1.1.143.6585\&rep=rep1\&type=pdf

Brown, J., Fazzari, S. and Petersen, B. (2009), "Financing innovation and growth: cash flow, external equity, and the 1990s R\&D boom", The Journal of Finance, Vol. 64 No. 1, pp. 151-185, available at: http://doi.wiley.com/10.1111/j.1540-6261.2008.01431.x

Chu, A. and Lai, C. (2013), "Money and the welfare cost of inflation in an R\&D growth model", Journal of Money, Credit and Banking, Vol. 45 No. 1, pp. 233-249, available at: http://doi.wiley.com/ 10.1111/j.1538-4616.2012.00568.x

Carlin, W. and Mayer, C. (2003), "Finance, investment, and growth", Journal of Financial Economics, Vol. 69 No. 1, pp. 191-226, available at: www.sciencedirect.com/science/article/pii/ S0304405X03001120

Chu, A., Cozzi, G., Furukawa, Y. and Liao, C. (2019), "Inflation and innovation in a schumpeterian economy with North-South technology transfer", Journal of Money, Credit and Banking, Vol. 51 Nos 2/3, pp. 683-719, available at: https://onlinelibrary.wiley.com/doi/abs/10.1111/ jmcb.12514

Chu, A., Cozzi, G., Lai, C. and Liao, C. (2015), "Inflation, R\&D and growth in an open economy”, Journal of International Economics, Vol. 96 No. 2, pp. 360-374, available at: www.sciencedirect.com/ science/article/pii/S0022199615000616

Čihák, M., Demirgüç-Kunt, A., Feyen, E. and Levine, R. (2018), "Benchmarking financial systems around the world", Policy Research Working Paper 6175, World Bank, available at: https:// papers.ssrn.com/sol3/papers.cfm?abstract_id=2152254

Cohen, W. and Levinthal, D. (2000), "Absorptive capacity: a new perspective on learning and innovation”, Strategic Learning in a Knowledge Economy, Elsevier, pp. 39-67, available at: http:// linkinghub.elsevier.com/retrieve/pii/B9780750672238500058

Crepon, B., Duguet, E. and Mairessec, J. (1998), "Research, innovation and productivity: an econometric analysis at the firm level", Economics of Innovation and New Technology, Vol. 7 No. 2, pp. 115-158, available at: www.tandfonline.com/action/journalInformation?journalCode=gein20

Czarnitzki, D. and Hussinger, K. (2018), "Input and output additionality of R\&D subsidies", Applied Economics, pp. 1-18, available at: www.tandfonline.com/action/journalInformation? journalCode $=$ raec20

D'Este, P., Iammarino, S., Savona, M. and von Tunzelmann, N. (2012), "What hampers innovation? Revealed barriers versus deterring barriers”, Research Policy, Vol. 41 No. 2, pp. 482-488, available at: www.sciencedirect.com/science/article/pii/S0048733311001764

Da Rin, M. and Penas, M. (2007), The Effect of Venture Capital on Innovation Strategies, Cambridge, MA, available at: www.nber.org/papers/w13636.pdf

Demirgüç-Kunt, A. and Maksimovic, V. (2002), "Funding growth in bank-based and market-based financial systems: evidence from firm-level data", Journal of Financial Economics, Vol. 65 No. 3, pp. 337-363, available at: www.sciencedirect.com/science/article/pii/S0304405X02001459

Denis, D. and Mihov, V. (2002), "The choice among bank debt, non-bank private debt and public debt: evidence from new corporate borrowings", Journal of Financial Economics, Vol. 70 No. 1, pp. 3-28, available at: http://citeseerx.ist.psu.edu/viewdoc/download?doi=10.1.1.8.1181\&rep= rep1\&type=pdf

Dosi, G. (1982), "Technological paradigms and technological trajectories: a suggested interpretation of the determinants and directions of technical change", Research Policy, Vol. 11 No. 3, pp. 147-162, available at: www.sciencedirect.com/science/article/abs/pii/0048733382900166

Durusu-Ciftci, D., Ispir, M. and Yetkiner, H. (2017), "Financial development and economic growth: some theory and more evidence", Journal of Policy Modeling, Vol. 39 No. 2, pp. 290-306, available at: www.sciencedirect.com/science/article/pii/S0161893816300631 
Edquist, C. (2005), "Systems of innovation: perspectives and challenges", in Fagerberg, J., Mowery, D.C. and Nelson, R.R. (Eds), The Oxford Handbook of Innovation, Oxford and New York, pp. 181-208.

Freeman, C. (1987), “Technology policy and economic performance: lessons from Japan”, London, Pinter, p. 34, available at: http://paper.shiftit.ir/sites/default/files/article/13LXIII

Freeman, C. (1995), "The 'national system of innovation' in historical perspective”, Cambridge Journal of Economics, Vol. 19, No. 1, Special issue on Technology and Innovation (February 1995), pp. 5-24.

Furman, J., Porter, M. and Stern, S. (2002), "The determinants of national innovative capacity”, Research Policy, Vol. 31 No. 6, pp. 899-933, available at: www.sciencedirect.com/science/article/pii/ S0048733301001524

Gur, N. and Avşar, V. (2016), "Financial system, R\&D intensity and comparative advantage", The Journal of International Trade and Economic Development, Vol. 25 No. 2, pp. 213-239, available at: www.tandfonline.com/doi/full/10.1080/09638199.2015.1045928

Hall, B. and Lerner, J. (2009), "The financing of R\&D and innovation”, Handbook of the Economics of Innovation, Vol. 1 No. 1, pp. 609-639, available at: www.merit.unu.edu

Hasan, I., Horvath, R. and Mares, J. (2018), "What type of finance matters for growth? Bayesian model averaging evidence", World Bank Economic Review, Vol. 32 No. 2, pp. 383-409, available at: https://academic.oup.com/wber/article-lookup/doi/10.1093/wber/lhw029

Hsu, P., Tian, X. and Xu, Y. (2014), "Financial development and innovation: cross-country evidence", Journal of Financial Economics, Vol. 112 No. 1, pp. 116-135, available at: https://www. sciencedirect.com/science/article/pii/S0304405X13003024

Iammarino, S., Sanna-Randaccio, F. and Savona, M. (2009), "The perception of obstacles to innovation. Foreign multinationals and domestic firms in Italy", Revue D'économie Industrielle, No. 125, pp. 75-104, available at: http://cournot.u-strasbg.fr/beta

Jaumotte, F. and Pain, N. (2005), "Innovation in the business sector", OECD Economic Department Working Papers 459, p. 58, available at: http://dx.doi.org/10.1787/688727757285

Lederman, D., Messina, J., Pienknagura, S. and Rigolini, J. (2014), "El emprendimiento en américa latina: Muchas empresas y poca innovación", available at: https:/elibrary.worldbank.org/doi/abs/ 10.1596/978-1-4648-0284-3

Lee, B. (2012), "Bank-based and market-based financial systems: time-series evidence", Pacific-Basin Finance Journal, Vol. 20 No. 2, pp. 173-197, available at: www. sciencedirect.com/science/article/ pii/S0927538X11000448

Levine, R. (1997), "Financial development and economic growth: views and agenda", Journal of Economic Literature, Vol. 35, pp. 688-726, available at: www.jstor.org/stable/2729790

Levine, R. (2002), Bank-Based or Market-Based Financial Systems: Which is Better?, Cambridge, MA, available at: www.nber.org/papers/w9138.pdf

Levine, R. (2004), "Finance and growth: theory and evidence", available at: www.nber.org/papers/ w10766

Luintel, K., Khan, M., Arestis, P. and Theodoridis, K. (2008), "Financial structure and economic growth", Journal of Development Economics, Vol. 86 No. 1, pp. 181-200, available at: www. sciencedirect.com/science/article/pii/S0304387807001009

Lundvall, B. (1999), "National business systems and national systems of innovation", International Studies of Management and Organization, Vol. 29 No. 2, pp. 60-77, available at: www. tandfonline.com/action/journalInformation?journalCode $=$ mimo20

Lundvall, B. (2010), National Systems of Innovation: Toward a Theory of Innovation and Interactive Learning, Anthem.

Madrid-Guijarro, A., García, D. and Van Auken, H. (2009), "Barriers to innovation among Spanish manufacturing SMEs”, Journal of Small Business Management, Vol. 47 No. 4, pp. 465-488, available at: http://doi.wiley.com/10.1111/j.1540-627X.2009.00279.x 
JEFAS 26,51

Méndez-Morales, A. (2019), "Show me the money: pecking order and funding sources for innovative firms in Colombia", Cuadernos de Administración, Vol. 32 No. 59.

Maskus, K., Neumann, R. and Seidel, T. (2012), "How national and international financial development affect industrial R\&D”, European Economic Review, Vol. 56 No. 1, pp. 72-83, available at: www. sciencedirect.com/science/article/pii/S0014292111000663

Nelson, R. (1959), "The simple economics of basic scientific research", Journal of Political Economy, Vol. 67 No. 3, pp. 297-306, available at: www. journals.uchicago.edu/doi/10.1086/258177

Nelson, R. (1993), National Innovation Systems: A Comparative Analysis, Oxford University Press.

Pellegrino, G. and Savona, M. (2017), "No money, no honey? Financial versus knowledge and demand constraints on innovation", Research Policy, Vol. 46 No. 2, pp. 510-521, available at: www. sciencedirect.com/science/article/pii/S004873331730001X

Prochniak, M. and Wasiak, K. (2017), "The impact of the financial system on economic growth in the context of the global crisis: empirical evidence for the EU and OECD countries", Empirica, Vol. 44 No. 2, pp. 295-337, available at: http://link.springer.com/10.1007/s10663-016-9323-9

Rajan, R. and Zingales, L. (1998), "Financial dependence and growth", American Economic Review, Vol. 88 No. 3, pp. 559-586, available at: www.nber.org/papers/w5758.pdf

Redding, S. (2002), "Path dependence, endogenous innovation, and growth", International Economic Review, Vol. 43 No. 4, pp. 1215-1248, available at: http://doi.wiley.com/10.1111/1468-2354.t01-100054

Romer, P. (1990), "Endogenous technological change”, Journal of Political Economy, Vol. 98 No. 5, Part 2, pp. S71-102.

Solow, R. (1956), “A contribution to the theory of economic growth", The Quarterly Journal of Economics, Vol. 70 No. 1, p. 65.

Stulz, R. (2003), "Financial structure, corporate finance and economic growth", International Review of Finance, Vol. 1 No. 1, pp. 11-38, available at: http://doi.wiley.com/10.1111/1468-2443.00003

Tee, L., Low, S., Kew, S. and Ghazali, N. (2014), "Financial development and innovation activity: evidence from selected East Asian countries", available at: www.researchgate.net/publication/ 284338665

Zysman, J. (1984), Governments, Markets, and Growth: Financial Systems and the Politics of Industrial Change, Cornell Studies in Political Economy.

\section{Appendix 1. Financial system specialization variable}

Financial specialization variable was constructed using principal component analysis, starting with a subgroup of variables related with stock markets (shares issued and negotiated, market capitalization as GDP percentage and number of firms issuing stock on exchange markets per million inhabitants), and a sub group of variables related with banking systems (Credits to private business as GDP percentage, total deposits on banking systems as GDP percentage and deposit money banks' assets to GDP). With these variables, we create two different factors or dimensions that each year collected the correlations among those variables and defined the impact factor in each country.

For this variable we use:

$$
f_{s S}=\left\{\begin{array}{l}
=1, \quad \text { Country has a specialized financial system (Bank based or stock based) } \\
=0, \quad \text { Mixed financial system (bank and stock markets) }
\end{array}\right.
$$


The main objective of the principal component analysis is to find a factor $\mathrm{M}=\left[m_{1}, m_{2}, m_{3}, \ldots, m_{p}\right]$, that is a linear combination of a subset of covariables of our original model $x=\left[x_{1}, x_{2}, x_{3}, \ldots, x_{p}\right]$, with $\mu=\left[u_{1}, u_{2}, u_{3}\right.$, $\left.\ldots, u_{p}\right]$ '. The methodology maximizes the variance of the elements in the matrix $m=x \mu$, so that, $\mu^{\prime} \mu=1$. This system is solved with an eigenvalue decomposition of the correlation matrix that makes:

Financial

system

specialization

$$
(R-\lambda I) \mu=0
$$

where $R$ is the partial correlation matrix of $(x)$ covariables, and $(\lambda)$ is the eigenvalue, that is the variance related to the components of $m$ vector. Countries in which both financial systems coexist must have higher correlations and the value of the dummy variable is 1 . On the other side, countries in which the correlation is low and one of the financial systems is preponderant, must have a value of zero.

\section{Appendix 2. Hausman test for model selection}

The idea behind the test is to contrast the hypothesis:

$$
\begin{aligned}
& H_{0}: \beta_{R E} \approx \beta_{F E} \\
& H_{1}: \beta_{R E} \not \beta_{F E}
\end{aligned}
$$

The test results are:

$$
\begin{aligned}
& \operatorname{Hausman}\left(\chi^{2}\right)=(b-B)^{\prime}\left[\left(\sigma^{2} b-\sigma^{2} B\right)^{-1}\right](b-B) \\
& \qquad\left(\chi^{2}\right)=82.815 \\
& \text { Prob }>\operatorname{chi} 2(10)=0.000
\end{aligned}
$$

where $b$ are fixed effect parameters and $B$ are parameters obtained using random-effects model. The difference between fixed and random effects parameters allows us to infer that we have enough statistic evidence to reject the null hypothesis, where the difference of coefficients is not systemic. Given that at least one of the models is inconsistent, statistical strategy tell us that, using a model like the one of the equation (2), we should use a fixed-effects model. 
JEFAS

26,51

60

Table A1.
Variable resume

\section{Appendix 3}

\begin{tabular}{lccccccc}
\hline Statistic & $\mathrm{N}$ & Mean & SD & Min & Pctl (25) & Pctl (75) & Max \\
\hline gerd & 484 & 49,0 & 13,8 & 16,5 & 39,0 & 59,3 & 90,7 \\
epc & 555 & $8.476,5$ & $7.378,3$ & 829,4 & $4.900,1$ & $9.058,0$ & $54.799,2$ \\
extri & 575 & 97,6 & 12,3 & 55,4 & 92,6 & 102,0 & 152,6 \\
irate & 629 & 3,1 & 4,4 & $-9,7$ & 1,1 & 3,9 & 52,9 \\
banks & 578 & 85,3 & 43,2 & 12,5 & 51,4 & 111,7 & 262,5 \\
mkcap & 551 & 64,8 & 47,9 & 1,5 & 29,3 & 89,9 & 265,1 \\
bonds & 528 & 2,0 & 1,9 & - & 0,8 & 2,7 & 18,1 \\
p_fte & 497 & 43,2 & 19,2 & 0,1 & 29,0 & 58,9 & 85,0 \\
conct & 577 & 67,4 & 19,4 & 21,4 & 53,3 & 82,4 & 100,0
\end{tabular}

Sources: Adapted from UNESCO Institute for Statistics (UIS), date of extraction December 2018; Cihák et al. (2018)

\section{Corresponding author}

Edgard Alberto Méndez-Morales can be contacted at: edgard.mendez@unimilitar.edu.co 